\title{
Decreased galanin mRNA levels in growth hormone-releasing hormone neurons after perinatally induced growth retardation
}

\author{
C T Huizinga, C B M Oudejans ${ }^{1}$ and H A Delemarre-van de Waal \\ Department of Pediatrics, Research Institute for Endocrinology, Reproduction and Metabolism, University Hospital 'Vrije Universiteit', Amsterdam, \\ The Netherlands \\ ${ }^{1}$ Department of Clinical Chemistry, Research Institute for Endocrinology, Reproduction and Metabolism, University Hospital 'Vrije Universiteit', Amsterdam, \\ The Netherlands \\ (Requests for offprints should be addressed to H A Delemarre-van de Waal, University Hospital 'Vrije Universiteit', Department of Pediatrics, PO Box 7057, \\ 1007 MB Amsterdam, The Netherlands; Email: h.delemarre@vumc.nl)
}

\begin{abstract}
Intrauterine growth retardation (IUGR) is associated with persistent postnatal growth retardation accompanied by dysfunction of the hypothalamic components of the growth hormone $(\mathrm{GH})$ axis. At the adult stage, this is reflected by increased somatostatin (SS) and decreased neuropeptide Y (NPY) mRNA levels, whereas the GHreleasing hormone $(\mathrm{GHRH}) \mathrm{mRNA}$ levels are normal and the output of GH remains unchanged. To extend our insight into the hypothalamic control of GH secretion in growth retarded rats, we determined galanin (GAL) mRNA levels at the adult stage of perinatally malnourished (i.e. IUGR and early postnatally food restricted) rats. Analyses included comparison of GAL mRNA levels in GHRH neurons in perinatally malnourished adult rats using a semi-quantitative double labeling in situ hybridization technique.
\end{abstract}

We report that IUGR is accompanied by a $60 \%$ decrease in GAL mRNA levels in all GHRH neurons in the male IUGR group whereas a tendency towards a decrease was observed in the male early postnatally food restricted (FR) group. These effects became more pronounced when the analysis was restricted to GHRH neurons coexpressing GAL mRNA i.e. decreased GAL mRNA levels were seen in both male and female IUGR rats and in FR males.

These data show that GAL mRNA levels in GHRH neurons are persistently decreased after perinatal malnutrition. Taking these results together with our previous data on SS, NPY and GHRH mRNA levels, we can conclude that IUGR leads to a reprogramming of the hypothalamic regulation of $\mathrm{GH}$ secretion.

Journal of Endocrinology (2001) 170, 521-528

\section{Introduction}

Postnatal growth is regulated primarily by the growth hormone (GH)/insulin-like growth factor-I (IGF-I) axis (Gluckman et al. 1991). The secretion of GH is regulated by the inhibitory neuropeptide somatostatin (SS) and the excitatory $\mathrm{GH}$-releasing hormone $(\mathrm{GHRH})$ which are secreted by neurons located, respectively, in the periventricular (PeN) and arcuate (ARC) nuclei in the hypothalamus (Tannenbaum 1991, Bluet-Pajot et al. 1998). Besides SS and GHRH, neuropeptide Y (NPY), which stimulates the secretion of SS thereby indirectly inhibiting GH release, affects the GH/IGF-I axis (Chabot et al. 1988, Rettori et al. 1990, Catzeflis et al. 1993, Chan et al. 1996b). Galanin (GAL), a 29-amino acid neuropeptide which is coexpressed in GHRH neurons, also plays a role in $\mathrm{GH}$ secretion (Niimi et al. 1990). A role for GAL in GH secretion has been postulated based on the observations that GAL stimulates the secretion of $\mathrm{GH}$ by induction of
GHRH in humans and rats (Bauer et al. 1986, Davis et al. 1987, Ottlecz et al. 1988). Moreover, treatment with GAL antiserum reduces the GH pulse amplitude (Maiter et al. 1990), and, as for GHRH, GAL mRNA levels increase throughout development, in parallel with the amplification of pulsatile GH secretion in male rats (Eden 1979). These observations suggest that the physiological role of GAL may be to enhance GHRH secretion and thereby $\mathrm{GH}$ release, and that GAL may contribute to the male pattern of GH secretion (Delemarre-van de Waal et al. 1994).

In recent studies, we have demonstrated that perinatal malnutrition results in a persistent postnatal growth retardation associated with increased SS mRNA levels in the PeN and decreased NPY mRNA levels in the ARC nucleus whereas GHRH mRNA expression and $\mathrm{GH}$ secretion and IGF-I levels are normal (Huizinga et al. 2000, Houdijk et al. 2000). The question arises whether at the adult stage GAL mRNA levels coexpressed in GHRH 
neurons are altered in perinatally malnourished rats and are part of the hypothalamic dysregulation. Therefore, we performed a semiquantitative double labeling in situ hybridization assay determining alterations in GAL gene expression in GHRH-containing neurons in the ARC nucleus of adult male and female rats subjected to perinatally induced growth retardation.

\section{Materials and Methods}

\section{Animals and surgical procedures}

Timed-pregnant Wistar rats were obtained from Harlan CPB (Rijswijk, The Netherlands) and were housed in a constant light-darkness cycle (lights on $0600 \mathrm{~h}$; lights off $1800 \mathrm{~h})$ in a temperature-controlled room $\left(22 \pm 1{ }^{\circ} \mathrm{C}\right)$. For experimental induction of IUGR, a modified method of Wigglesworth was used as described in detail elsewhere (Huizinga et al. 2000). Briefly, on day 17 of pregnancy females were anesthetized and the uterine arteries were ligated. After surgery, females were allowed to recover and to give birth. Pups were considered intrauterine growth retarded (IUGR) if their weights at postnatal day 2 were below minus 2 s.D. (weight $<5.3 \mathrm{~g}$ ) of the mean weight of control pups born from non-operated mothers. The litter size of both IUGR and control animals was restricted to 6 pups per mother.

Early postnatal growth failure was induced by food restriction (FR) during the weaning period by increasing litter size to 20 pups (male/female ratio 1:1) per mother from postnatal day 1 onwards (Huizinga et al. 2000).

For each experimental group, the mothers had free access to rat chow and tap water. The pups remained with their mother until weaning at day 25 . After weaning, the rats were housed in groups of 2-3 animals per cage with free access to food and tap water. All procedures were approved by the Institutional Animal Ethic Committee.

Both animal models resulted in a persistent postnatal growth retardation into adulthood without any signs of catch-up growth (Houdijk et al. 2000, Huizinga et al. 2000).

\section{Experimental design}

Levels of GAL mRNA in GHRH neurons in the ARC nucleus were compared among the groups of IUGR $(n=6)$, FR $(n=6)$ and control $(n=6)$ rats at postnatal days 72-74 (adulthood) in both males and females.

\section{Tissue preparation}

Adult rats were killed between $0900 \mathrm{~h}$ and $1100 \mathrm{~h}$. The brains were rapidly dissected and frozen in dry-ice-cooled 2 -methylbutane. Brains were stored at $-80{ }^{\circ} \mathrm{C}$ until further processing. Coronal cryostat sections were cut at $20 \mu \mathrm{m}$ and thaw-mounted on 2\% 3-aminopropylethoxysilanecoated slides. Consecutive brain sections were cut starting rostrally at the beginning of the ARC nucleus (bregma $-2.12 \mathrm{~mm}$ ) and continuing caudally to the end of the ARC nucleus (bregma $-4.30 \mathrm{~mm}$ ) (Paxinos \& Watson 1986). Four sets of slides were collected; every fourth slide was placed into a given set. Slides were stored in $-80{ }^{\circ} \mathrm{C}$ until in situ hybridization was performed; one set (about 20 sections per animal) was used for in situ hybridization.

\section{GHRH cRNA probe synthesis and labeling}

Digoxigenin(dig)-labeled (anti)sense cRNA probes complementary to GHRH mRNA were generated by promoter-mediated in vitro transcription of linearized pGEM4 plasmids (Promega, Madison, WI, USA) containing a 198-basepair (bp) EcoRI-HindIII fragment of the entire rat GHRH-43 coding sequence as well as a portion of the coding region for a 30-amino acid peptide of unknown function (R Steiner, Seattle, WA, USA). Antisense GHRH cRNA riboprobes were made by linearizing the plasmid with EcoRI (Roche Molecular Biochemicals, Indianapolis, IN, USA) and transcribing with T7 RNA polymerase (Promega). Sense GHRH cRNA probes were made by linearizing with HindIII and transcribing with SP6 RNA polymerase in the presence of 35\% dig-11UTP (Roche). Residual DNA was digested with RQ1 DNase (Promega; $1 \mathrm{U} / \mu \mathrm{g}$ DNA). The cRNA probes were precipitated with $1 / 10$ vol. $3 \mathrm{M}$ sodium acetate $(\mathrm{NaAc}) \mathrm{pH} 5.2$ and 2.5 vol. ethanol at $-20^{\circ} \mathrm{C}$. Labeled precipitated riboprobes were resuspended in TE $(10 \mathrm{mM}$ Tris, $1 \mathrm{mM}$ disodium ethylenediaminetetraacetate (EDTA)) pH 7.6. The identity and integrity of the probes were analyzed by chemiluminescent identification of sizeseparated, immobilized probes (Van Wijk et al. 1995). Briefly, serial dilutions of the probes were size-separated by gel electrophoresis and transferred to uncharged nylon membranes (Hybond-N; Amersham, 's-Hertogenbosch, The Netherlands), and analyzed by chemiluminescence using immunodetection with anti-dig antibody Fab fragments conjugated to alkaline phosphatase (anti-dig AP; Roche) followed by chemiluminescence with CSPD (Roche). Since the exact yield of the transcription reaction with dig-UTP for the GHRH probes cannot be derived, a test in situ hybridization was performed to determine empirically the optimal concentration for these probes.

\section{Galanin probe synthesis and labeling}

(Anti)sense GAL cRNA riboprobes were generated by in vitro transcription of the 680-bp segment of rat GAL cDNA inserted into the EcoRI site of Bluescript M13 (Stratagene, San Diego, CA, USA; R Steiner). Following linearization with HindIII, the ${ }^{35} \mathrm{~S}$-labeled antisense probe was generated through the use of T7 RNA polymerase in the presence of $35 \%\left[{ }^{35} \mathrm{~S}\right] \mathrm{UTP}$ (NEN Life Sciences, 
Boston, MA, USA). Sense probes were made by linearizing with SmaI and transcribing with T3 RNA polymerase in the presence of $35 \%\left[{ }^{35} \mathrm{~S}\right] \mathrm{UTP}$. Transcription was terminated by addition of RQ1 DNase and the probes were precipitated. The riboprobes were resuspended in $100 \mathrm{mM}$ dithiothreitol (DTT). The identity and integrity of the transcripts were verified by polyacrylamide gel electrophoresis and an overnight exposure on a light sensitive Kodak X-OMAT film (Eastman Kodak Company, Rochester, NY, USA).

\section{In situ hybridization}

To demonstrate the specificity of the binding of the GHRH and GAL cRNA probes, sense cRNA probes were used in an in situ hybridization test assay. The control hybridization to the mRNA strand with the sense probes resulted in the absence of photographic grain clusters (for the GAL probe) and purple-stained dig-labeled cells (for the GHRH probe), while the antisense probes showed probe concentration-dependent cytoplasmic signals with anatomical specificity demonstrating specific binding. Furthermore, in this in situ hybridization test assay, different concentrations of antisense GHRH cRNA dig-probes (range 1:50-1:500 $\mu \mathrm{l}$ probe/ $\mu$ l hybridization mix) and antisense GAL cRNA ${ }^{35}$ S-probes (range 10 000-160 000 d.p.m./ $\mu \mathrm{l}$ ) were used to empirically determine the optimal probe concentration. The optimal probe concentration for the GHRH antisense probe appeared to be 1:150 and for the GAL antisense probe 40000 d.p.m. $/ \mu$ l.

Two double labeling in situ hybridization assays were performed; the tissues from the male rats were run in one assay and the tissues from the female rats were run in another assay. Sections were air-dried at room temperature and fixed for $20 \mathrm{~min}$ in freshly prepared $4 \%$ paraformaldehyde in $0 \cdot 1 \mathrm{M}$ phosphate-buffered saline (PBS; $\mathrm{pH} 7 \cdot 4$ ), rinsed three times for $5 \mathrm{~min}$ in PBS and dipped in water. After acetylation for $10 \mathrm{~min}$ with $0 \cdot 25 \%$ acetic anhydride in $1 \%$ triethanolamine and two washing steps for $5 \mathrm{~min}$ each in PBS, sections were rinsed in $2 \times$ standard saline citrate (SSC; $\mathrm{pH} \mathrm{7 \cdot 0)}$ for at least $5 \mathrm{~min}$. The slides were prehybridized for $2 \mathrm{~h}$ at $37^{\circ} \mathrm{C}$ with hybridization solution containing $50 \%$ formamide, $10 \%$ dextran sulfate, $1 \times$ Denhardt's solution, $0 \cdot 2 \times \mathrm{SSC}, 500 \mu \mathrm{g} / \mathrm{ml}$ denatured herring sperm DNA (Roche) and $250 \mu \mathrm{g} / \mathrm{ml}$ tRNA (Sigma-Aldrich, St. Louis, MO, USA). After prehybridization, the denatured antisense GHRH cRNA probe and antisense GAL cRNA probe in hybridization solution containing $10 \mathrm{mM} \mathrm{DTT}$, were applied at a concentration of 1:150 (for the GHRH cRNA probe) and $2.5 \times 10^{6}$ d.p.m./slide (for the GAL cRNA probe). Sections were covered with parafilm and hybridized overnight in moist chambers at $55^{\circ} \mathrm{C}$. The following day, sections were washed two times in $4 \times$ SSC containing $1 \mathrm{mM}$ DTT (SSC-DTT) followed by treatment with $30 \mu \mathrm{g} / \mathrm{ml}$ RNase A (Roche) in RNase buffer (10 mM Tris, $1 \mathrm{mM}$ EDTA,
$50 \mathrm{mM} \mathrm{NaCl} ; \mathrm{pH} \mathrm{8.0)}$ for $30 \mathrm{~min}$ and a 15 -min wash in RNase buffer at $37^{\circ} \mathrm{C}$. The sections were washed under high stringency two times for $5 \mathrm{~min}$ in $2 \times$ SSC-DTT, $5 \mathrm{~min}$ in $1 \times$ SSC-DTT and $5 \mathrm{~min}$ in $0.5 \times$ SSC-DTT at room temperature followed by two washes for $30 \mathrm{~min}$ each in $0 \cdot 1 \times$ SSC-DTT at $65^{\circ} \mathrm{C}$. After a 5 -min wash in $0 \cdot 1 \times$ SSC-DTT at room temperature, the sections were washed for $5 \mathrm{~min}$ in buffer $1(100 \mathrm{mM}$ Tris, $150 \mathrm{mM}$ $\mathrm{NaCl} ; \mathrm{pH} 7 \cdot 5)$. The sections were blocked for $1 \mathrm{~h}$ in freshly prepared $1 \%$ blocking reagent (Roche) in buffer 1 and washed two times for $10 \mathrm{~min}$ in buffer 1 . The sections were then incubated for $1 \mathrm{~h}$ with anti-dig AP (1:1000 diluted in buffer 1) at $37^{\circ} \mathrm{C}$. After antibody incubation, sections were washed two times for $15 \mathrm{~min}$ in buffer 1 at room temperature and for $5 \mathrm{~min}$ in buffer $2(100 \mathrm{mM}$ Tris, $100 \mathrm{mM} \mathrm{NaCl}, 5 \mathrm{mM} \mathrm{MgCl}$; $\mathrm{pH}$ 9·5). The sections were incubated overnight at $4{ }^{\circ} \mathrm{C}$ with color solution $(0 \cdot 24 \mathrm{mg} /$ $\mathrm{ml}$ levamisole, $300 \mu \mathrm{g} / \mathrm{ml}$ nitro-bluetetrazolium (SigmaAldrich), $170 \mu \mathrm{g} / \mathrm{ml}$ 5-bromo-4-chloro-3-indolylphosphatase (Sigma-Aldrich) in buffer 2). The color reaction was stopped by two washes for $15 \mathrm{~min}$ in TE $\mathrm{pH} 8 \cdot 0$. Sections were dipped in water and $70 \%$ ethanol and air-dried at room temperature. Before being dipped in emulsion, the slides were dipped in 3\% parlodion (Fisher Scientific, Fair Lawn, NJ, USA) which was dissolved in isoamyl acetate (Sigma-Aldrich) to prevent chemographic artefacts in the autoradiographic steps. The slides were allowed to air-dry for at least $1 \mathrm{~h}$ and were stored at room temperature until emulsion dipping was performed.

\section{Autoradiography}

The slides were dipped in emulsion (Ilford K5; Ilford, Paramus, NJ, USA) that had been diluted $1: 1$ in $2 \%$ glycerol solution and heated to $45{ }^{\circ} \mathrm{C}$. The slides were allowed to air dry for $1 \mathrm{~h}$, placed in light-tight boxes, exposed for 7 days at $4{ }^{\circ} \mathrm{C}$, developed, and dehydrated in $70 \%$ ethanol before coverslips were applied.

\section{Semiquantitative analysis of cellular $m R N A$}

Prior to image analysis of the in situ hybridization, sexmatched slides were assigned a random three-letter code, alphabetized, and read in random order. The sections were viewed under a Zeiss Axioskop (Zeiss, New York, NY, USA) equipped with a $\times 40$ immersion oil objective under darkfield illumination with a halogen light source. The image analysis system consisted of a PixelGrabber Video Aquisition board (Perceptics, Knoxville, TN, USA) attached to a MacIntosh IICi computer. Video images were obtained by a Cohu model 4913 CCD camera (Cohu, San Diego, CA, USA) whereby each analyzed image was an average of 32 video frames. In each section, the number of grains over each dig-labeled cell in the ARC was determined by use of the UW Grain Counting Analysis 

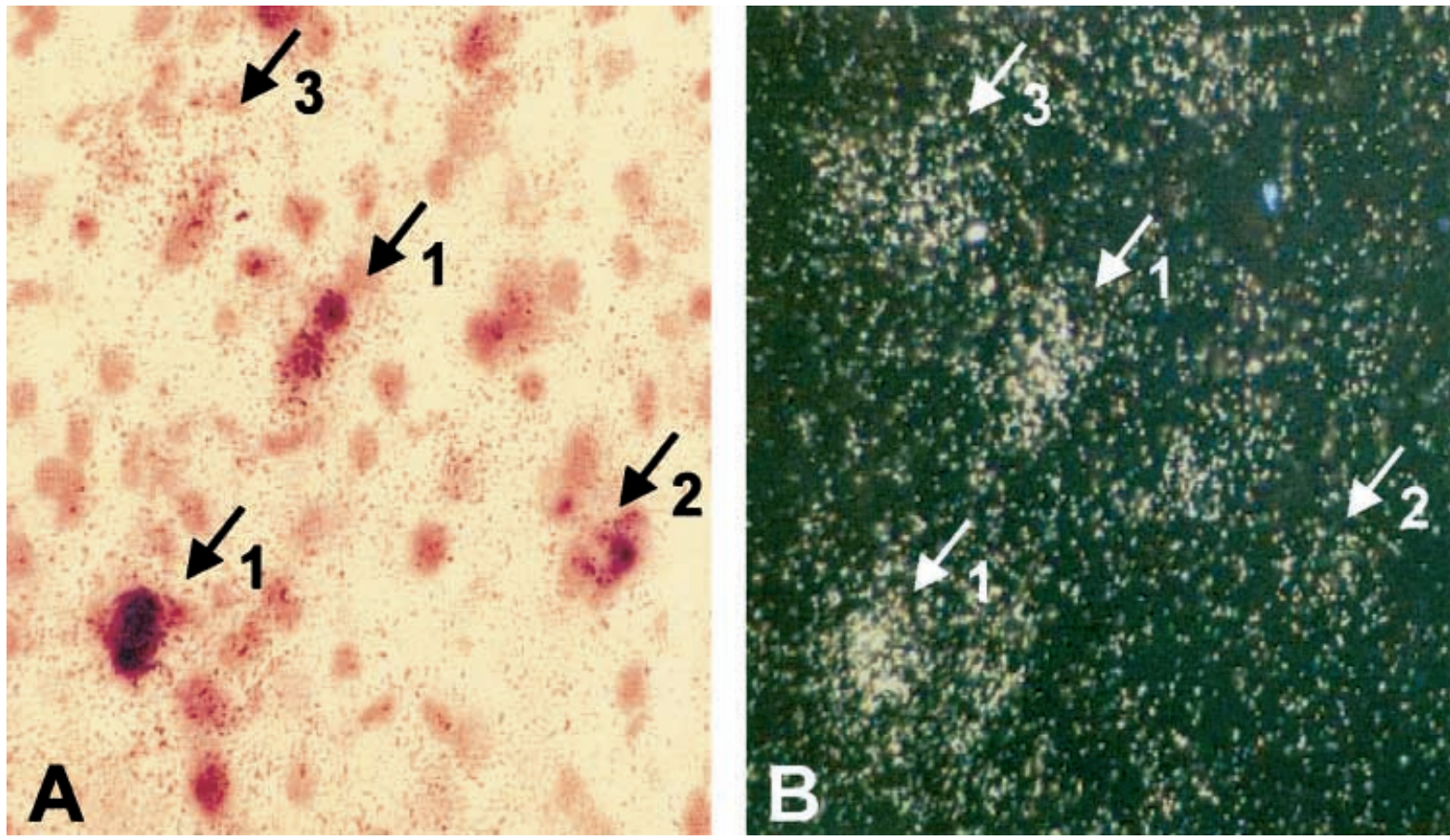

Figure 1 Photomicrographs of neurons in the ARC nucleus of an adult female control rat under brightfield (A) and darkfield (B) illumination after double label in situ hybridization for GHRH and GAL. Under brightfield illumination, the presence of dig-labeled GHRH mRNA is indicated by dark-stained cell bodies (arrows numbered 1 and 2). Silver grains from the radioactively labeled GAL probes appear as black dots in brightfield and white dots in darkfield. The silver grain clusters indicate cells containing GAL mRNA (arrows numbered 1 and 3). Cell number 1 is double labeled for GHRH and GAL mRNA, cell number 2 is single labeled for GHRH mRNA and cell number 3 is single labeled for GAL mRNA.

Program II (D Clifton, Seattle, WA, USA). A purplestained dig-labeled GHRH cell was first identified and selected under brightfield illumination. The silver grains overlying the cell were then visualized under darkfield illumination with the halogen light source and the number of grains per cell was determined (Fig. 1).

The GAL mRNA levels in GHRH neurons were determined in two ways. The first option consisted of determination of GAL mRNA levels in all GHRH cells. For this, all dig-labeled cells were selected and in these GHRH-positive cells the number of grains per cell, i.e. GAL mRNA level, was counted. In this way, GHRH cells without co-expression of GAL mRNA were included in the semiquantitative measurements. The second option to determine GAL mRNA levels in GHRH neurons was to identify and select all dig-labeled GHRH cells with distinct co-expression of GAL mRNA (thereby excluding all GHRH cells without coexpression of GAL mRNA). Then, the number of grains per cell in these double-labeled cells was counted. In this way, only the double-labeled cells were counted. Arbitrarily, we defined distinct coexpression of GAL mRNA when the number of grains was more than five grains per GHRH neuron.

\section{Statistical analysis}

The mean number of grains per cell and the total number of counted cells for each individual animal were calculated. They were expressed as the mean \pm S.E.M. for each group. Statistical differences between the control, IUGR and FR groups on GAL mRNA expression in GHRH neurons and on the number of GHRH or GAL/GHRH cells were assessed by using a one-way ANOVA followed by Fisher's protected least significant difference test. Differences were considered statistically significant when $P \leq 0 \cdot 05$.

\section{Results}

Semiquantitative analysis of GAL $m R N A$ levels in all GHRH neurons in the ARC nucleus of adult IUGR and FR rats

Measurement of GAL mRNA levels in all GHRH neurons (Fig. 1) showed a diminished GAL gene expression in the IUGR males of $60 \%(6 \cdot 5 \pm 0 \cdot 6$ grains/cells; $P=0 \cdot 041)$ compared with their controls $(10 \cdot 8 \pm 1 \cdot 8$ grains/cell), whereas the GAL mRNA expression in 


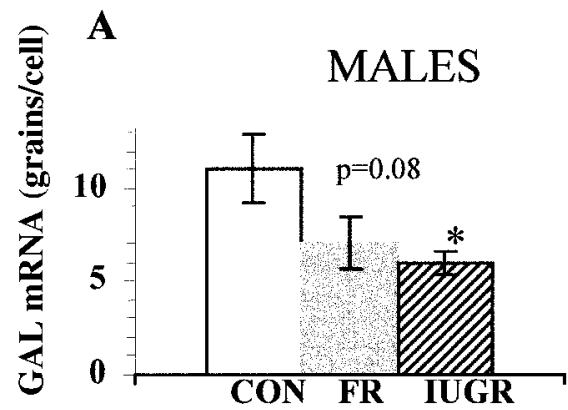

C

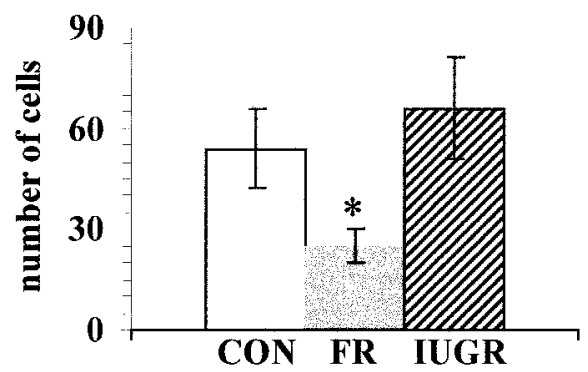

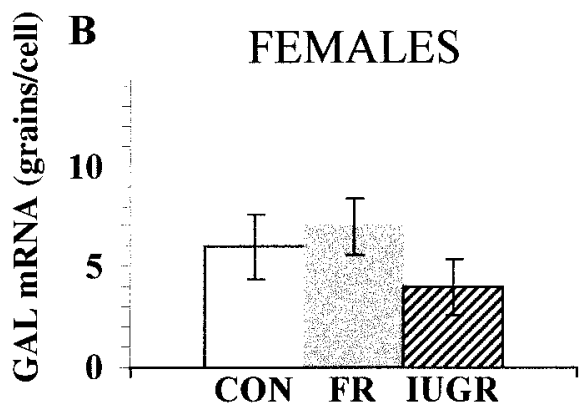

D

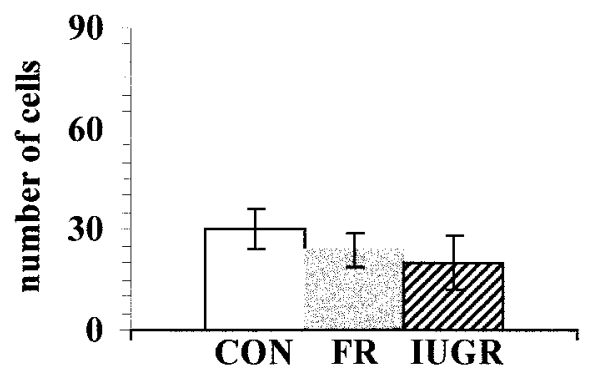

Figure 2 GAL mRNA signal levels in GHRH neurons and the number of counted GHRH neurons in the ARC nucleus of adult male and female IUGR, FR and control (CON) rats. (A) and (B) depict GAL mRNA levels in GHRH neurons in males and females respectively, and (C) and (D) depict the number of counted $\mathrm{GHRH}$ neurons in males and females respectively. Values are given as means \pm S.E.M. ${ }^{*} P<0 \cdot 05$ compared with controls.

IUGR females (3.82 $\pm 1 \cdot 4$ grains/cell) was not different from their matched controls $(6 \cdot 6 \pm 1 \cdot 4$ grains/cell). GAL mRNA levels in FR males (7.2 $\pm 1 \cdot 4$ grains/cell) showed a tendency towards a decrease compared with their controls although this was not significant $(P=0 \cdot 084)$ whereas GAL mRNA levels in FR females $(6 \cdot 6 \pm 1 \cdot 4$ grains/cell) were not different compared with their controls (Fig. 2A, B).

The number of GHRH-containing neurons in the ARC was decreased in the FR males $(25 \pm 5$ cells; $P=0 \cdot 023)$ compared with the control group ( $54 \pm 12$ cells) whereas the IUGR males showed no difference in the number of GHRH neurons ( $66 \pm 15$ cells) compared with the control group. The number of cells containing GHRH mRNA in IUGR females ( $20 \pm 8$ cells) and FR females $(24 \pm 5$ cells) was not different from their controls $(30 \pm 6$ cells) (Fig. 2C, D).

Semiquantitative analysis of GAL $m R N A$ levels in GHRH neurons distinctly coexpressing GAL in the ARC nucleus of adult IUGR and FR rats

Semiquantitative analysis of GAL mRNA in selected GHRH neurons coexpressing GAL (expression $>5$ grains/ cell; Fig. 1) showed a 71\% decrease in GAL mRNA levels in the IUGR males $(10 \cdot 1 \pm 0 \cdot 8$ grains/cell; $P=0 \cdot 025)$ and a $74 \%$ decrease in the male FR group $(10 \cdot 5 \pm 1 \cdot 2$ grains/ cell; $P=0.043)$ compared with their sex-matched control group (14.2 \pm 1.4 grains/cell). The GAL mRNA expression in GHRH/GAL neurons of IUGR females was significantly decreased by $49 \% \quad(5 \cdot 8 \pm 2 \cdot 4$ grains/cell; $P=0 \cdot 041)$ compared with their controls (12 $\pm 1 \cdot 6$ grains/ cell). The GAL gene expression in the female FR group $(11.6 \pm 1.8$ grains/cell) was not altered compared with their controls (Fig. 3A, B).

The number of neurons expressing both GHRH and GAL mRNA was not different in the IUGR males (42 \pm 11 cells) and FR males (17 \pm 3 cells) compared with the control group ( $42 \pm 10$ cells). This was also observed in the IUGR females $(10 \pm 5$ cells) and FR females $(13 \pm 3$ cells), where no difference was found in the number of GHRH and GAL neurons compared with controls (15 \pm 5 cells) (Fig 3C, D).

\section{Discussion}

In the present study, the hypothalamic regulation of $\mathrm{GH}$ secretion of rats subjected to perinatal malnutrition was investigated. IUGR children with a persistent growth 


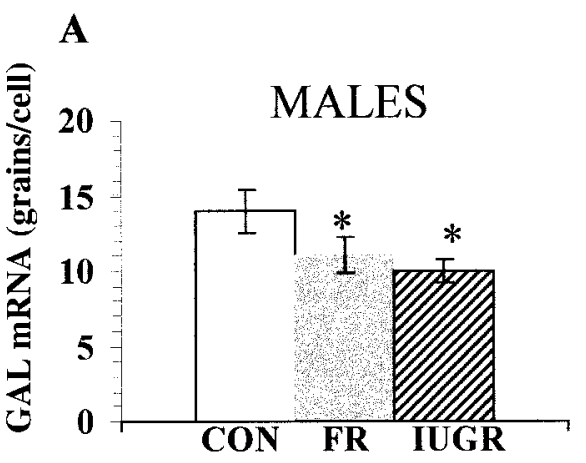

C

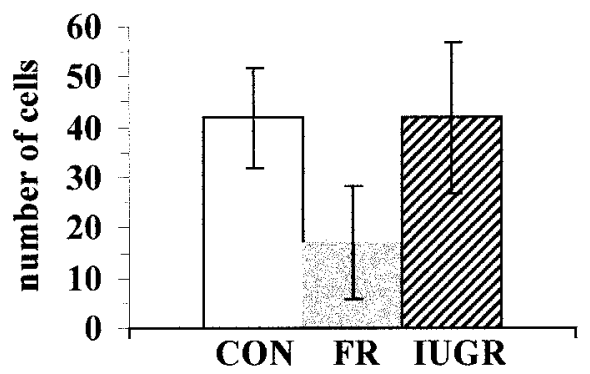

$\mathrm{B}$

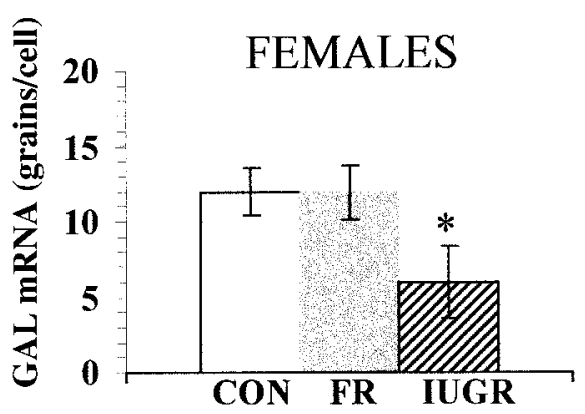

D

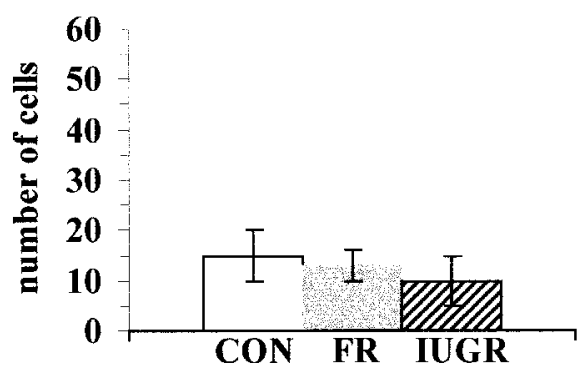

Figure 3 GAL mRNA levels in GHRH neurons coexpressing GAL mRNA and the number of counted GHRH/GAL neurons in the ARC nucleus of adult male and female IUGR, FR and control (CON) rats. (A) and (B) depict GAL mRNA levels in GHRH/GAL neurons in males and females respectively, and (C) and (D) depict the number of counted GHRH/GAL neurons in males and females respectively. Values are given as means \pm S.E.M. ${ }^{*} P<0 \cdot 05$ compared with controls.

failure have a decreased GH secretion based on impaired GH pulse amplitudes, as well as decreased IGF-I levels (de Waal et al. 1994). Ligation of the uterine artery in the rat, mimicking the suboptimal uteroplacental function leading to IUGR, leads to a persistent growth retardation which is not accompanied by alteration in GH secretion and IGF-I levels. However, the hypothalamic regulation of $\mathrm{GH}$ secretion is disturbed in these IUGR animals, reflected in the elevated SS mRNA levels and the decreased NPY mRNA levels whereas the GHRH mRNA levels remain within the normal range (Huizinga et al. 2000, 2001). Early postnatal food restriction in the rat results also in a postnatal growth retardation which is, in contrast to the IUGR animals, not accompanied by alterations in the hypothalamic regulation of $\mathrm{GH}$ secretion, i.e. there are normal levels of SS, GHRH and NPY mRNA (Huizinga et al. 2000, 2001). To extend our study of the regulatory control of $\mathrm{GH}$, we investigated whether perinatal malnutrition was accompanied by changes in GAL mRNA expression in GHRH neurons and in the number of these neurons in the ARC nucleus. Although GAL is widely distributed in the central nervous system and is involved in several regulatory mechanisms, only the subset of GHRH neurons expressing GAL are involved in the regulation of GH secretion by controlling GH pulse amplitude (Bauer et al. 1986, Davis et al. 1987, Ottlecz et al. 1988, Niimi et al. 1990, Delemarre-van de Waal et al. 1994). Therefore, we performed semi-quantitative analyses of GAL mRNA in neurons coexpressing GHRH.

In all experimental groups, we observed no difference in the number of neurons expressing both GHRH and GAL mRNA, nor in the number of NPY- and SScontaining neurons (Huizinga et al. 2001), indicating that early malnutrition applied prenatally as well as early postnatally did not affect the number of neurons responsible for the control of GH secretion. This does not automatically imply that the activity of these neurons remained unchanged. It might be possible that the number of dendrites or outgrowth of neurites is altered after perinatal malnutrition, inducing a changed network interactivity between the different neurons. However, we found a decrease in the number of GHRH-containing cells in the male FR group. This is in contrast with our earlier study (Huizinga et al. 2001) in which we described 
no differences in the number of GHRH cells in the male FR group. We are aware of this contradiction, and we are not able to explain the differences in observations. One factor that may play a role could be that the data derive from two different in situ hybridization procedures. In our former study we used a radioactive labeled probe which is more sensitive.

The results of the present study demonstrate that IUGR associated with a persistent postnatal growth retardation is accompanied by a decreased GAL mRNA expression in GHRH neurons in the ARC nucleus in adult male rats. In FR males, a similar tendency was observed. In females of both the IUGR and FR groups, no changes in GAL expression were seen. However, since the measurements for these observations also included GHRH neurons that do not coexpress GAL, the relative decrease in GAL mRNA levels could also be explained by a shift in the percentage of GHRH cells with or without GAL mRNA expression. This possibility can be excluded as additional measurements restricted to the subset of cells coexpressing GAL and GHRH confirmed the initial observations. In fact, the effects of experimentally induced growth restriction became more pronounced: decreased GAL mRNA levels in GHRH neurons in the ARC nucleus were observed in both male and female IUGR rats as well as in FR male rats.

The decreased levels of GAL mRNA in neurons expressing both GHRH and GAL may be explained by an altered food intake. Several studies have shown that GAL plays an important regulatory role in food intake (Crawley et al. 1990, Kalra et al. 1999, Plagemann et al. 1999b, Dube et al. 2000). In neonatally overfed rats, the number of GAL neurons is increased reflecting increased GAL secretion leading to hyperphagia (Plagemann et al. 1999b). The decreased GAL activity in GAL coexpressing GHRH neurons may reflect hypophagia of the IUGR and male FR animals. A sufficient food intake is demonstrated by equal growth rates during the postnatal phase in the IUGR and control rats, suggesting that the IUGR rats adjust their food intake in proportion to their body weight (Houdijk et al. 2000). This means that, although the ratio of food intake versus body weight is similar in all animals, the growth retarded animals exhibit a lower appetite than the control group. Accordingly, and given the fact that neurons of the ARC project to important appetiteregulating nuclei including the paraventricular nucleus (Kalra et al. 1999, Plagemann et al. 1999a), the lower levels of GAL could reflect a different resetting of the satiety center in the growth-retarded animals as a consequence of perinatal malnutrition.

In the physiological control of postnatal GH secretion, GAL inhibits SS release thereby stimulating GH release from the pituitary (Liposits et al. 1993, Chan et al. 1996a). The IUGR animals have decreased GAL mRNA levels and increased SS mRNA levels (Huizinga et al. 2000). However, this decrease in GAL mRNA levels in GHRH neurons and elevated SS mRNA levels do not result in an alteration in GH secretion in adult IUGR animals (Houdijk et al. 2000). The influence of increased SS mRNA levels on GH secretion may be counteracted by GHRH, resulting in normal GH secretion. A previous study showed that GHRH mRNA levels in the ARC nucleus are not altered in adult IUGR animals (Huizinga et al. 2001). Moreover, the decreased GAL levels do not seem to influence GHRH gene expression in the ARC nucleus.

Recently, Ohtaki et al. (1999) cloned galanin-like peptide (GALP) which is identical to the biologically active N-terminal portion of galanin and selectively recognizes galanin receptor 2 (GalR2) with high affinity. The distribution of GALP mainly in the ARC nucleus (Jureus et al. 2000, Larm \& Gundlach 2000) which is different from that of NPY, GAL and GHRH suggests that GALP has its own organization and function. It might be possible that GALP acts on neurons in the ARC nucleus or anterior pituitary that express GalR 2 receptor, thereby influencing $\mathrm{GH}$ release directly at the pituitary level or indirectly via GHRH. This might explain why the observed decrease in GAL mRNA levels in IUGR animals does not result in changes in GHRH and GH levels, although this is very speculative and remains to be investigated.

The decreased GAL mRNA levels in the FR group seem to influence $\mathrm{GH}$ secretion since the FR animals have increased baseline GH levels (E C Houdijk, personal communication) converting the adult male GH secretory pattern into a more feminine one. Therefore, we can speculate that the sexual dimorphism between the female and male FR groups is removed since the males show a more feminine pattern whereas the females show a normal GH secretory pattern. This is in contrast with the IUGR animals, in which we find normal GAL mRNA levels and normal GH levels, suggesting that there is still a normal sexual dimorphism in GAL and GH secretion.

Engelbregt et al. (2000) recently showed that the onset of puberty is delayed in IUGR males and females and in FR males whereas the FR females have a normal onset of puberty. The physiological increase in GAL throughout development in males is presumably the result of androgen exposure (Delemarre-van de Waal et al. 1994). An impaired developmental increase in GAL might be due to the late start of puberty.

Summarizing, in both models of growth retardation, we did not observe changes in the number of GHRH neurons coexpressing GAL mRNA. However, we did find a malfunction in these cells as measured by decreased levels of GAL mRNA in neurons also expressing GHRH in the adult IUGR animals and male FR animals. These results, together with previous studies from our laboratory where we found changes in SS and NPY but not in GHRH mRNA expression (Huizinga et al. 2000, 2001), suggest a changed programming of the central GH regulation. 


\section{References}

Bauer FE, Ginsberg L, Venetikou M, MacKay DJ, Burrin JM \& Bloom SR 1986 Growth hormone release in man induced by galanin, a new hypothalamic peptide. Lancet 2 192-195.

Bluet-Pajot MT, Epelbaum J, Gourdji D, Hammond C \& Kordon C 1998 Hypothalamic and hypophyseal regulation of growth hormone secretion. Cellular and Molecular Neurobiology 18 101-123.

Catzeflis C, Pierroz DD, Rohner-Jeanrenaud F, Rivier JE, Sizonenko PC \& Aubert ML 1993 Neuropeptide Y administered chronically into the lateral ventricle profoundly inhibits both the gonadotropic and the somatotropic axis in intact adult female rats. Endocrinology 132 224-234.

Chabot JG, Enjalbert A, Pelletier G, Dubois PM \& Morel G 1988 Evidence for a direct action of neuropeptide $\mathrm{Y}$ in the rat pituitary gland. Neuroendocrinology 47 511-517.

Chan YY, Grafstein-Dunn E, Delemarre-van de Waal HA, Burton KA, Clifton DK \& Steiner RA 1996a The role of galanin and its receptor in the feedback regulation of growth hormone secretion. Endocrinology 137 5303-5310.

Chan YY, Steiner RA \& Clifton DK $1996 b$ Regulation of hypothalamic neuropeptide-Y neurons by growth hormone in the rat. Endocrinology 137 1319-1325.

Crawley JN, Austin MC, Fiske SM, Martin B, Consolo S, Berthold M, Langel U, Fisone G \& Bartfai T 1990 Activity of centrally administered galanin fragments on stimulation of feeding behavior and on galanin receptor binding in the rat hypothalamus. Journal of Neuroscience 10 3695-3700.

Davis TM, Burrin JM \& Bloom SR 1987 Growth hormone (GH) release in response to GH-releasing hormone in man is 3-fold enhanced by galanin. Journal of Clinical and Endocrinological Metabolism 65 1248-1252.

Delemarre-van de Waal HA, Burton KA, Kabigting EB, Steiner RA \& Clifton DK 1994 Expression and sexual dimorphism of galanin messenger ribonucleic acid in growth hormone-releasing hormone neurons of the rat during development. Endocrinology 134 665-671.

Dube MG, Kalra SP \& Kalra PS 2000 Hypothalamic galanin is up-regulated during hyperphagia and increased body weight gain induced by disruption of signaling in the ventromedial nucleus. Peptides 21 519-526.

Eden S 1979 Age- and sex-related differences in episodic growth hormone secretion in the rat. Endocrinology 105 555-560.

Engelbregt MJ, Houdijk ME, Popp-Snijders C \& Delemarre-van de Waal HA 2000 The effects of intra-uterine growth retardation and postnatal undernutrition on onset of puberty in male and female rats. Pediatric Research 48 803-807.

Gluckman PD, Douglas RG, Ambler GR, Breier BH, Hodgkinson SC, Koea JB \& Shaw JH 1991 The endocrine role of insulin-like growth factor I. Acta Paediatrica Scandinavica Supplement 372 97-105.

Houdijk EC, Engelbregt MJ, Popp-Snijders C \& Delemarre-van de Waal H 2000 Endocrine regulation and extended follow up of longitudinal growth in intrauterine growth-retarded rats. Journal of Endocrinology 166 599-608.

Huizinga CT, Oudejans CB, Steiner RA, Clifton DK \& Delemarre-van de Waal HA 2000 Effects of intrauterine and early postnatal growth restriction on hypothalamic somatostatin gene expression in the rat. Pediatric Research 48 815-820.

Huizinga CT, Oudejans CB \& Delemarre-van de Waal HA 2001 Persistent changes in somatostatin and neuropeptide Y mRNA levels but not in growth hormone-releasing hormone mRNA levels in adult rats after intrauterine growth retardation. Journal of Endocrinology 168 273-281.
Jureus A, Cunningham MJ, McClain ME, Clifton DK \& Steiner RA 2000 Galanin-like peptide (GALP) is a target for regulation by leptin in the hypothalamus of the rat. Endocrinology 141 2703-2706.

Kalra SP, Dube MG, Pu S, Xu B, Horvath TL \& Kalra PS 1999 Interacting appetite-regulating pathways in the hypothalamic regulation of body weight. Endocrine Reviews 20 68-100.

Larm JA \& Gundlach AL 2000 Galanin-like peptide (GALP) mRNA expression is restricted to arcuate nucleus of hypothalamus in adult male rat brain. Neuroendocrinology 72 67-71.

Liposits Z, Merchenthaler I, Reid JJ \& Negro-Vilar A 1993 Galanin-immunoreactive axons innervate somatostatin-synthesizing neurons in the anterior periventricular nucleus of the rat. Endocrinology 132 917-923.

Maiter DM, Hooi SC, Koenig JI \& Martin JB 1990 Galanin is a physiological regulator of spontaneous pulsatile secretion of growth hormone in the male rat. Endocrinology 126 1216-1222.

Niimi M, Takahara J, Sato M \& Kawanishi K 1990 Immunohistochemical identification of galanin and growth hormone-releasing factor-containing neurons projecting to the median eminence of the rat. Neuroendocrinology 51 572-575.

Ohtaki T, Kumano S, Ishibashi Y, Ogi K, Matsui H, Harada M, Kitada C, Kurokawa T, Onda H \& Fujino M 1999 Isolation and cDNA cloning of a novel galanin-like peptide (GALP) from porcine hypothalamus. Journal of Biological Chemistry 274 37041-37045.

Ottlecz A, Snyder GD \& McCann SM 1988 Regulatory role of galanin in control of hypothalamic-anterior pituitary function. PNAS 85 9861-9865.

Paxinos G \& Watson C 1986 The Rat Brain in Stereotaxic Coordinates, ed 2. London: Academic Press Limited.

Plagemann A, Harder T, Rake A, Melchior K, Rohde W \& Dorner G $1999 a$ Increased number of galanin-neurons in the paraventricular hypothalamic nucleus of neonatally overfed weanling rats. Brain Research 818 160-163.

Plagemann A, Harder T, Rake A, Voits M, Fink H, Rohde W \& Dorner G 19996 Perinatal elevation of hypothalamic insulin, acquired malformation of hypothalamic galaninergic neurons, and syndrome $\mathrm{x}$-like alterations in adulthood of neonatally overfed rats. Brain Research 836 146-155.

Rettori V, Milenkovic L, Aguila MC \& McCann SM 1990 Physiologically significant effect of neuropeptide $\mathrm{Y}$ to suppress growth hormone release by stimulating somatostatin discharge. Endocrinology 126 2296-2301.

Tannenbaum GS 1991 Neuroendocrine control of growth hormone secretion. Acta Paediatrica Scandinavica Supplement 372 5-16.

Van Wijk I, Van Vugt JM, Könst AA, Mulders MA, Nieuwint AW \& Oudejans CB 1995 Multiparameter in situ analysis of trophoblast cells in mixed cell populations by combined DNA and RNA in situ hybridization. Journal of Histochemistry and Cytochemistry $\mathbf{4 3}$ 709-714.

de Waal WJ, Hokken-Koelega AC, Stijnen T, de Muinck K \& Drop SL 1994 Endogenous and stimulated GH secretion, urinary GH excretion, and plasma IGF-I and IGF-II levels in prepubertal children with short stature after intrauterine growth retardation. The Dutch Working Group on Growth Hormone. Clinical Endocrinology 41 621-630.

Received 11 May 2001

Accepted 30 May 2001 